\begin{tabular}{l} 
POLITEIA POLIA: Jurnal Ilmu Politik \\
Politeia: Jurnal Ilmu Politik, 11 (1) (2019): 49-59 \\
ISSN 0216-9290 (Print), ISSN 2549-175X (Online) \\
Available online https://jurnal.usu.ac.id/index.php/politeia \\
\hline
\end{tabular}

\title{
Gender Stereotype and the Voting Behavior of the Balinese Society in the 2014 Legislative Election
}

\author{
Kadek Dwita Apriani ${ }^{1}$ * \& Riaty Raffiudin ${ }^{2)}$ \\ 1)Doctoral Program in Political Science, University of Indonesia FISIP Depok, Indonesia \\ 2)Department of Political Science, Faculty of Social and Political Science Universitas \\ Indonesia Depok, Indonesia
}

Received in December 2018, Approved in December 2018, Published January 2019

\begin{abstract}
Abstrak
Penelitian ini menjelaskan keterkaitan antara gender stereotype yang hidup dalam budaya patriarki di tengah masyarakat Bali dengan kecenderungan memilih calon perempuan dalam pemilulegislative tahun 2014. Metode yang digunakan dalam penelitian ini adalah metode penelitian kuantitatif dengan sampel sebesar 800 dan tersebar proporsional di seluruh kabupaten/kota di Bali, sehingga margin of error dalam penelitian ini adalah $3 \%$ pada tingkat kepercayaan 95\%. Teknik sampling yang digunakan adalah multistage random sampling. Temuan penelitian ini memperlihatkan bahwa tendensi masyarakat Bali untuk memilih caleg perempuan relatif rendah, hanya 4\% pada Pemilu 2014. Hal ini disebabkan oleh faktor gender stereotype, dimana isu atau kebijakan yang dinilai lebih mampu diselesaikan oleh politisi perempuan jumlahnya sangat sedikit. Hampir seluruh isu yang menjadi permasalahan dalam keseharian masyarakat Bali dinilai oleh responden lebih baik diselesaikan oleh politisi laki-laki.
\end{abstract}

Kata Kunci: Bali, Gender Stereotype, Perilaku Memilih

\begin{abstract}
This research explains the relationships between gender stereotypes that live inside patriarchal culture among Balinese with voting behaviour of female candidates in the 2014 legislative election. Using quantitative method, the number of the samples are 800 which are proportionally spread in all Bali regencies and cities. The margin of error of this research is 3\% at $95 \%$ confidence level. The sampling technique used is multi stage random sampling. The research findings suggest that in the 2014 legislative election, only 4\% of the Balinese respondents voted for female candidates. This is due to the gender stereotyping factor, where there are very few issues or policies that are considered more capable of being resolved by female politicians. Almost all the issues that become problems in the daily life of the Balinese people are considered by the respondents to be better resolved by male politicians.
\end{abstract}

Keyword: Bali, Gender Stereotype, Voting Behavior

How to cite: Apriani, K. D. \& Raffiudin, R. (2018), Gender Stereotype and the Selecting Behavior of the BalineseSociety in the 2014 Legislative Election, Politeia: Jurnal Ilmu Politik, Vol 11, (1): 49-59

*Corresponding author:

E-mail: kadek88@gmail.com 


\section{INTRODUCTION}

Bali is a region that is very typical of the aspects of society and culture. Culture in this province is still preserved and influences society's order, including the position of women in society and their access to the political sphere. Communities in this area are known to have a strong patriarchal culture and very neat structure of indigenous peoples. Various decisionmaking processes in traditional social organizations in Bali are taken by the mechanism of deliberation. Note that meetings (sangkep) for traditional decision-making can only be attended by male family heads (Rhoads 2012: 43). The aspirations of women are considered to be entrusted to the head of the family to be conveyed in the decision-making process. The main reason for these conditions is the busyness of women with domestic affairs and preparation of ceremonial facilities such as offerings, so that the domain of decision making is left to the male family head.

For this reason, Balinese women are called not having access to decisionmaking processes in the smallest community. This is the reason why Balinese women are not confident and not trained to organize; make decisions; and further acting in the political sphere. This is the cause of the reluctance of Balinese women to take part in the political sphere.

Unlike the case with the political realm, Balinese women contribute greatly to the economic sphere. Data shows that the contribution of women in Bali to the family economy reached 46.5\%. (Astiti, 2003: 95) The high contribution of women in the economic field in Bali is not linear with women to take part in the realm of politics, especially electoral politics. (www.antarabali.com) This has resulted in a masculine nuance in electoral politics in the Patriarchal culture region that is still very much felt. This masculine nuance is clearly seen in the legislative and post-conflict local elections, where in 2014 only six of the twelve political parties nominated women in all electoral districts in Bali. (http//:news.okezone.com) Not a few political parties in Bali have been reprimanded due to the non-fulfillment of the quota of $30 \%$ of women in the list 
of candidates in a particular electoral district. The subsequent effects were later seen in the results of the legislative elections in Bali after the New Order.

There are no women sitting as legislators at the national level, both the Indonesian House of Representatives and the Republic of Indonesia Regional Representatives from the blood of the electoral district (Dapil) of Bali. At the regional level, the conditions are relatively better than the national, but women's electability in the local parliament in Bali is still below 10\% and makes the DPRD Bali Province the third worst provincial DPRD in terms of women's representation in local parliaments throughout Indonesia, after West Papua and Maluku North. The number of women in the Bali provincial DPRD who were elected in the 2014 elections were five people, and the remaining 50 were men. This means that the percentage of women in the Bali provincial DPRD is only $9.1 \%$. This number has increased from $7.5 \%$ in the previous period. (http://nasional.tempo.co )

There are various assumptions about the causes of the low interest of women involved in politics and their electability in the electoral momentum in Bali, but this has never been studied quantitatively from the perspective of voters. In fact, it is very important to capture the public perception of female candidates, so that electoral strategies for female candidates can be arranged to achieve the target of increasing the number of female representatives in parliament. Therefore, the problem to be answered in this study is: What is the tendency of patriarchal cultures such as Bali in choosing female candidates in an electoral momentum?

To dissect the problems mentioned above, the author uses gender stereotype theory. Gender stereotyping is rooted in the socialization of the roles of men and women, where women's activities are more private, while men are public. (Fox \& Oxley, 2003) The traditional gender role stated above is often attributed to candidates in an election. Gender stereotyping in seeing candidates can be divided into two namely belief stereotypes and trait stereotypes. Belief refers more to 
ideology and policy, where female candidates are usually seen paying more attention to issues such as education, health, environment, consumer protection, and poverty. While male candidates in belief stereotypes are seen as more competent in issues such as military, security, economy and business. In trait stereotypes, female candidates are often seen as candidates who are patient, compromised and oriented towards society. While men are seen as being more confident, assertive, and active. (Fox \& Oxley, 2003)

This topic is widely discussed in scientific journals written in the 1990s to 2013. The majority of research loci on this topic are American and European regions. The main assumption in research on gender stereotypes at election momentum is that voters judge candidates through their gender. These findings were found more through research that applied experimental methods.

Fox and Oxley (2003) conducted a study using data from executive elections in all states in the United States in 1978-1998 to see the effect of gender stereotyping on real elections (not experiments). The purpose of Fox and Oxley's research is to see whether the influence of gender stereotyping is greater in the nomination phase or in the election phase. Gender stereotyping is said to be rooted in the socialization of the roles of men and women, where women's activities are more in the private sphere, while men are in the public sphere.

The presence of gender stereotyping in the political area, has important consequences on several things, for example voters prefer men to occupy political positions, especially national level executives. That is, this gender stereotyping influence the electability of candidates based on issues in a particular area. The presence of Gender stereotyping can sometimes help the choice of women, but more often at a disadvantageous position. Gender stereotyping in the end can provide an explanation of why the number of women in public positions through the election mechanism is far from representative. Because regions with issues closer to gender stereotyping are fewer women and party leaders prefer candidates with masculine characteristics. 


\section{RESEARCH METHODOLOGY}

This research is a descriptive quantitative research because the purpose of this study is to provide an overview of the tendency of patriarchal cultures such as Bali to elect female candidates in an electoral momentum, rather than seeking causal relationships between variables. The main data collection is done by structured interviews with respondents using a questionnaire. The total number of respondents in this study was 800 people. The level of trust in this study was $95 \%$ and MoE was 3\%. (De Vaus, 2006: 81) Sampling was done by multistage random sampling method, taking into account the proportion of the population in each district in Bali.

In each district several villages were randomly drawn in proportion to the district. In each village 5 banjars were taken in simple random order. Then in each banjar 2 families were taken in a simple random manner, then one respondent was taken in each household with the Kish Grid system. The proportion of gender in this study was also maintained to be 50:50 with the mechanism of odd questionnaire numbers for men and even for female respondents. The stages in Multistage Random Sampling that are carried out are illustrated in the scheme below.

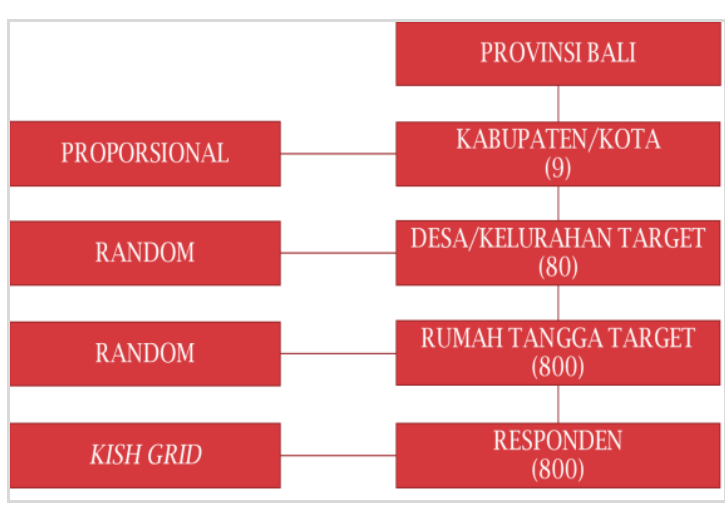

Picture 1. Stages of Sampling

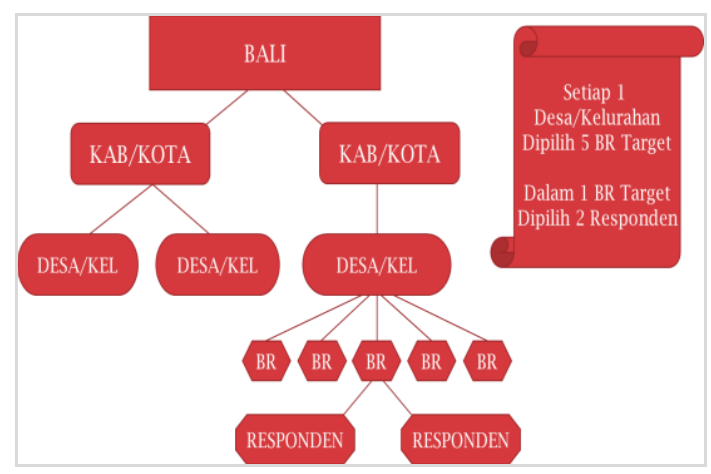

Picture 2. Advanced Stages of Sampling

Retrieval of field data was carried out in September - October 2016 to see the behavior of choosing respondents in the last election before 2016, namely in the 
2014 Election and also differences in male and female voter satisfaction on the performance of women legislative members in the 2014 election results.

\section{RESULTS AND DISCUSSION}

Before discussing more about the findings generated from this research, it is better to look first at the profile of respondents representing the Balinese population in 2016. The table below shows the distribution of respondents based on the municipal area or district and the gender of the respondents. As explained in the methodology section above, gender balance is maintained and the proportion of respondents is adjusted to the number of respondents per district.

Table 1 Profile of Respondents by Gender and

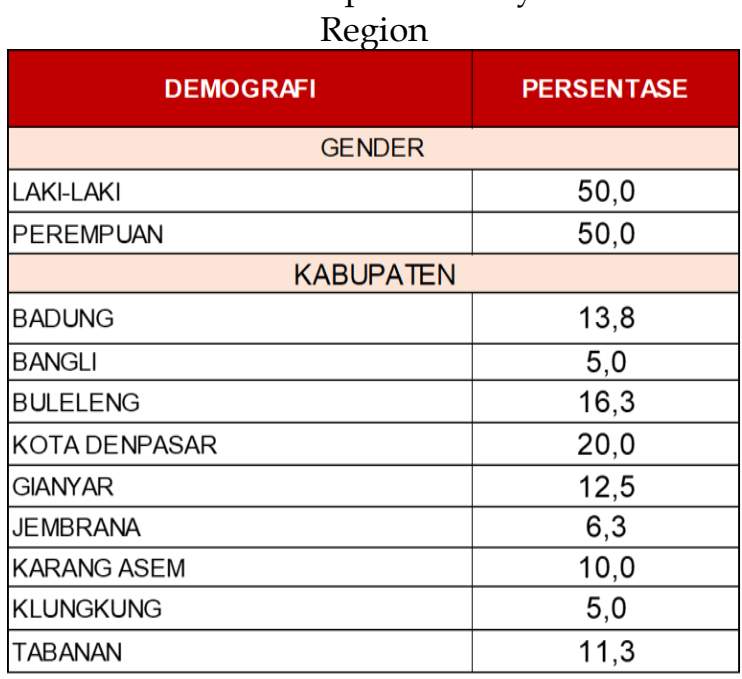

Source: Processed from the results of a survey conducted by the author
Next is the profile of respondents based on age. From the data read in the figure below, it is known that the highest proportion of respondents is in the age range of 36 to 45 years, and the least is the respondents over the age of 65.

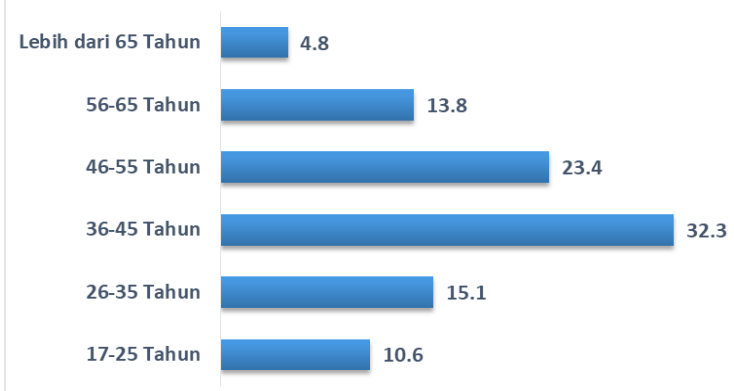

Picture 3 Age of Respondents

Source: Processed from the results of a survey conducted by the author

The next important component that must be seen from the respondent's profile is the respondent's education level. The data reflected in figure 4 shows that most Balinese people have received education to the middle and upper levels. The number of educated voters in Bali is less than 
$30 \%$

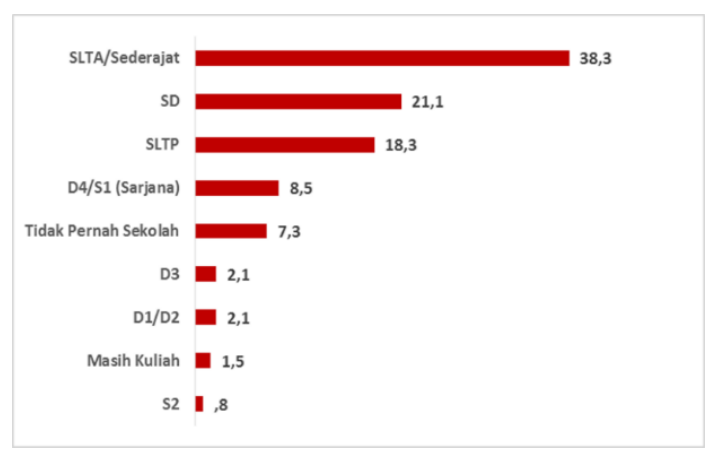

Picture 4 Education of Respondents

Source: Processed from the results of a survey conducted by the author

After exposure to the respondent's profile, we then enter the results and findings of the study. Data from the results of a survey conducted on 800 samples in all districts in Bali shows that only $4 \%$ of Bali voters stated that they chose female candidates in the previous election (2014). As many as $57 \%$ of the electorate said they chose male candidates in the legislative elections. $32 \%$ said they forgot whether he chose male or female candidates considering the election had been conducted for the year before the survey was conducted, and $7 \%$ of respondents said they did not vote in the 2014 election. The data is presented in the diagram below.

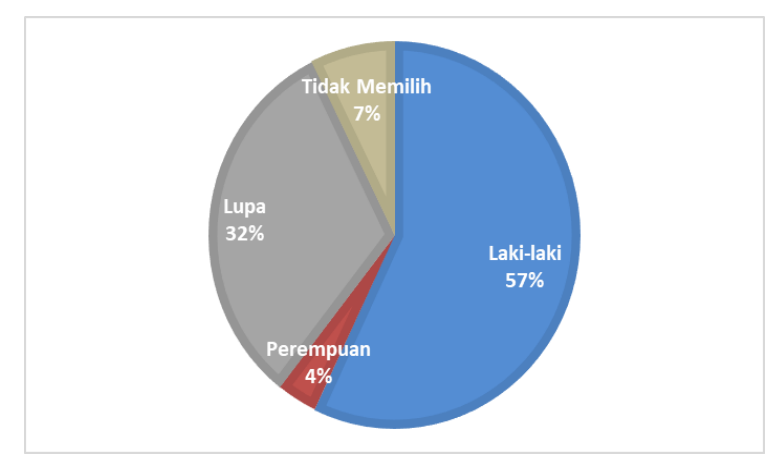

Picture 5 Respondents' Selected Gender

Candidates in Bali in the 2014 Legislative Election

Source: Processed from the results of a survey conducted by the author

The aggregate data above confirms that in regions with characteristics such as Bali, where patriarchal culture becomes dominant, the tendency of voters to elect female candidates in legislative elections is relatively low. The quota of $30 \%$ of women in the candidate list is indeed sought by all political parties in Bali, but the tendency of voters to elect women as representatives in parliament is still very small. This happens in all segments of the voters. Data on cross tabulation between gender voters and gender selected candidates in the 2014 election further explained that there was no difference between the gender of the chosen candidates from male and female 
voters. Data on this matter can be seen in the table in Bahwah.

Table 2 Cross Tabulation between Voter Gender and Gender of Selected Candidates in the 2014 Election

\begin{tabular}{|l|c|c|c|c|}
\hline \multirow{2}{*}{ Gender Pemilih } & \multicolumn{4}{|c|}{ Gender Caleg Pilihan dalam Pemilu 2014 } \\
\cline { 2 - 5 } & Laki-laki & Perempuan & Lupa & Tidak Memillh \\
\hline Laki-laki & $56.8 \%$ & $3.0 \%$ & $32.4 \%$ & $7.8 \%$ \\
\hline Perempuan & $57.3 \%$ & $4.0 \%$ & $31.8 \%$ & $7.1 \%$ \\
\hline
\end{tabular}

Source: Processed from the results of a survey conducted by the author

The data above explains that both male and female voters have a greater tendency to choose male candidates in an electoral momentum in Bali. The next cross tabulation makes it possible to read any region in Bali which tends to be more conducive for female candidates than in other regions. Three of the nine regencies / cities in Bali read more conducive to female legislative candidates than other regions.

Table 3 Cross Tabulation between Regions and Gender of Selected Candidates in the 2014 Election

\begin{tabular}{|l|c|c|c|c|}
\hline \multicolumn{1}{|c|}{ KAB/KOTA } & LAKI-LAKI & PEREMPUAN & LUPA & $\begin{array}{c}\text { TIDAK } \\
\text { MEMILIH }\end{array}$ \\
\hline BADUNG & $42.7 \%$ & $7.3 \%$ & $41.8 \%$ & $8.2 \%$ \\
\hline BANGLI & $32.5 \%$ & $7.5 \%$ & $52.5 \%$ & $7.5 \%$ \\
\hline BULELENG & $68.8 \%$ & $0.0 \%$ & $28.1 \%$ & $3.1 \%$ \\
\hline KOTA DENPASAR & $63.1 \%$ & $3.1 \%$ & $21.9 \%$ & $11.9 \%$ \\
\hline GIANYAR & $52.0 \%$ & $2.0 \%$ & $40.0 \%$ & $6.0 \%$ \\
\hline JEMBRANA & $48.0 \%$ & $4.0 \%$ & $40.0 \%$ & $8.0 \%$ \\
\hline KARANG ASEM & $53.8 \%$ & $7.5 \%$ & $30.0 \%$ & $8.8 \%$ \\
\hline KLUNGKUNG & $65.0 \%$ & $0.0 \%$ & $22.5 \%$ & $12.5 \%$ \\
\hline TABANAN & $67.8 \%$ & $2.2 \%$ & $28.9 \%$ & $1.1 \%$ \\
\hline
\end{tabular}

Source: Processed from the results of a survey conducted by the author

Badung Regency, Bangli and Karangasem look more conducive for female candidates than the other six regions. In the three districts, as many as $7.5 \%$ of their voters claimed to elect female candidates in the 2014 election. This could be verified through the number of women legislative members from the region concerned. Karangasem, for example, is the electoral district that sends the highest number of women representatives to the Bali provincial DPRD from the 2014 election results. Three of the five female legislative members in the Bali provincial DPRD 2014 election results are representatives of the easternmost district in the province, Karangasem. The figure also places Election District 7 Karangasem as an electoral district with the highest number of women compared to the eight other electoral districts in the province of Bali. (http://kpud- 
Kadek Dwita Apriani \& Riaty Raffiudin, Gender Stereotype and the Selecting Behavior of the

baliprov.go.id ) The proportion of men and women in the Karangasem electoral district can be fairly balanced. Of the seven representatives of Karangasem who sit in the provincial DPRD in Bali, four of them are male, and three are women.

Next related to gender set -ortype, as stated in the section on the theoretical basis above, voters tend to judge that women are more qualified in solving certain problems. Female candidates are usually seen paying more attention to issues such as education, health, environment, consumer protection, and poverty. While male candidates are seen as more competent in issues such as the military, security, economy and business. The presence of gender stereotyping in the political area, has important consequences on several things, for example voters prefer men to occupy political positions. This means that gender stereotyping affects the electability of candidates based on issues in a particular area. The presence of Gender stereotyping can sometimes help the choice of women, but more often at a disadvantageous position.
Data related to gender politicians who are considered better by respondents in resolving the daily problems faced by the Balinese community can be seen in the table below.

Table 4 Tabulation results from the question "Are Male or Female Politicians You Overvalued Able to Resolve the Following Problems?"

\begin{tabular}{|l|c|c|c|}
\hline \multicolumn{1}{|c|}{ Permaslahan } & Laki-Laki & Perempuan & Tidak Tahu \\
\hline Pendidikan yang tidak merata & 62.3 & 30.8 & 7.0 \\
\hline Kemiskinan yang meningkat & 68.5 & 24.0 & 7.5 \\
\hline Lingkungan yang rusak & 64.8 & 27.8 & 7.3 \\
\hline Mahalnya harga kebutuhan pokok & 32.0 & 62.3 & 5.8 \\
\hline Sulitnya mencari lapangan kerja & 74.9 & 17.8 & 7.3 \\
\hline Kerusakan Jalan dan Jembatan & 87.8 & 4.8 & 7.5 \\
\hline
\end{tabular}

Source: Processed from the results of a survey conducted by the author

Problems that Balinese voters consider to be a problem that is better resolved by women than men are only a matter of prices of basic needs Education, environment and poverty issues that in the theory of gender stereotyping should be judged by the public to be better resolved by women. man. Although the number of voters who stated that women were better able to solve educational problems was quite high, which was around $30 \%$, the 
number of voters in Bali who considered men more able to solve the problem of education equity reached $62 \%$.

Issues that are most often perceived as problems in Bali such as employment and infrastructure tend to be seen as very masculine issues and entrusted to male politicians. At least the voters considered that male politicians were better able to solve the problem of employment and infrastructure than female politicians. As many as $74 \%$ of voters think that male politicians are better able to solve difficult problems in finding jobs. Only $17 \%$ of voters considered that women were more qualified to solve this problem. Likewise with infrastructure problems such as roads and bridges. Only $4.8 \%$ of voters say this problem is better resolved by women. As many as $87 \%$ of voters consider male politicians better at solving this problem.

In general it can be said that voters in Bali trust male politicians more in solving various problems faced by society. This is also related to the conditions in which Balinese women are not trained in decision-making processes. This prayer was seen from the start as a male domain. Gender stereotyping in the end can provide an explanation of why the number of women in public positions through the election mechanism is far from representative. Because the issue that is closer to gender stereotyping of women, especially in Bali, is far less.

The foregoing also influences the perception of the Balinese public about the performance of female politicians. The following data provides an overview of public assessments of the performance of women legislators in Bali.

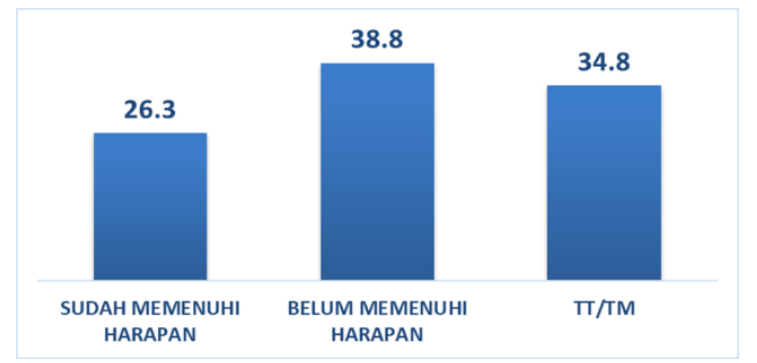

Picture 6 Tabylation Results from Questions "Do you think the Performance of Women's Legislative Members in Bali Has Fulfilled Expectations?"

Source: Processed from the results of a survey conducted by the author

The data above shows that as many as $38.8 \%$ of voters in Bali stated that the performance of female legislators in Bali 
Kadek Dwita Apriani \& Riaty Raffiudin, Gender Stereotype and the Selecting Behavior of the

did not meet expectations. Only 26\% who assessed the performance of female politicians in Bali as a result of the 2014 election met the voters' expectations. The remaining $34 \%$ said they did not know so they could not assess the performance of female politicians in Bali.

\section{CONCLUSION}

The tendency of Balinese voters to elect women candidates in legislative elections looks still low. Only $4 \%$ of voters said they voted for female candidates in the last election (2014). This is caused by several factors, including gender stereotype factors, where women are not considered qualified enough to solve problems that are felt by the wider community, such as employment and infrastructure problems.

This affected the public assessment regarding the performance of female politicians in the Bali parliament. Only $26 \%$ of voters considered that the performance of female politicians had met the expectations of voters. The voter number stating that female politicians have not met voter expectations is around $38 \%$. This number is thought to be related to various problems which the public sees as masculine and cannot be resolved by women. That way, it can be said that gender stereotypes are closely related to voting behaviour in the 2014 legislative elections in patriarchal cultures such as Bali.

\section{BIBLIOGRAPHY}

Astiti, T. I. P. (2003). Jalan Berliku Menuju Politik Praktis" dalam Nyoman Dharma Putra (ed), Bali Menuju Jagaditha: Aneka Perspektif. Denpasar: Pustaka Bali Post.

De Vaus,D, 2006, Research Design in Social Research, London: SAGE Publication

Fox, R. L. \& Zoe M. O. "Gender Stereotyping in State Executive Elections: Candidate Selection and Success", The Journal of Politics, Vol. 65, No. 3 (Aug., 2003)

Rhoads, E. (2012). “Women's Political Participation in Indonesia: Decentralisation, Money Politics and Collective Memory in Bali", dalam Journal of Current Southeast Asian Affairs, (Vol 31, No 2, 2012) 
http://www.antarabali.com/berita/50132/

menakar-kualitas-perempuan-bali-diranah-politik come at 13 Maret 2016

http:// news.okezone.com/read/2013/07/ 14/340/836749/2014-bali-bertaburcaleg-perempuan come at 13 Maret 2016 http://nasional.tempo.co/read/news/2014 /01/30/078549629/calegperempuan-bali-dipaksa-berjuanglebih-keras/3 come at 12 Maret 2016 http://kpudbaliprov.go.id/index.php?pg= lelangdetail\&id $=50$ come at 25 Januari 201 
Kadek Dwita Apriani \& Riaty Raffiudin, Gender Stereotype and the Selecting Behavior of the 